\title{
THE PHILOSOPHIC PRACTITIONER
}

\section{John Tribe}

\begin{abstract}
This paper develops principles for the ordering of the curriculum for tourism higher education. The framework proposed comprises four key domains of vocational action, vocational reflection, liberal reflection and liberal action. The framework enables the problems of curricula that are over-focused in one part of curriculum space to be surfaced. It also enables the case to be made, and the content outlined, for a tourism higher education which educates philosophic practitioners. These would be graduates who deliver efficient and effective tourism services whilst at the same discharging the role of stewardship for the development of the wider tourism world in which these services are delivered.
\end{abstract}

Keywords: Philosophic, liberal, vocational, action, reflection, stewardship.

\section{INTRODUCTION}

Tourism is the world's biggest industry. Undergraduates are studying tourism in ever increasing numbers (Airey 1997). But curriculum studies for higher education in general, and tourism in particular, are not well developed. The nature of graduateness, and the principles underpinning the development of tourism degrees are undertheorised. For example in the UK, The Quality Assurance Agency for Higher Education (QAA) (QAA 2000) has recently published benchmark statements for a number of degree subjects including tourism. But there is no discernible theoretical underpinning to accompany these benchmarks (Tribe 2000b). This paper addresses this shortcoming by its focus on one key question - By what principles should the vocational tourism curriculum be ordered?

It may be thought that the purposes of a vocational curriculum in tourism are selfevidently to equip graduates to operate in their chosen career. But this is to overlook an important feature of big industries like tourism. For as well as generating consumer satisfaction, employment and wealth, these industries leave their imprint on the world in other ways. They forge a distinctive industrial landscape and cause profound change in patterns of social and economic relationships.

A special burden is therefore placed on tourism education. For as economic prosperity and consumer satisfaction are generated from the development of tourism, changes to people and place also occur. Actions to enhance the business of tourism produce distant effects or externalities. A distinctive tourism society is affected and tourism world (Tribe 1999) is constructed. This wide tourism society and world comprises not just tourists and tourism businesses but additionally any individuals, communities, governments and physical environments affected by tourism.

Slagheaps and pneumoconiosis are part of the aftermath of previous waves of industrial development such as coal mining. If the development of tourism is to avoid 
these kinds of externalities then curriculum elements designed to further the business of tourism must be complemented by elements to nurture tourism's wider society and the developing tourism world. This paper links the aims of tourism higher education with those of tourism's wider society so that the curriculum model proposed involves shaping tourism's society as well as serving it. This is in contrast to many other curriculum recommendations (e.g. Holloway 1995; Koh 1995; QAA 2000; Shepherd 1997) where curriculum aims are not explicitly addressed but which implicitly are directed towards servicing the tourism economy.

The article is organised in the following way. First its methodology is outlined. Next, the curriculum concept of the philosophical practitioner is clarified and the central framework is developed using the two axes of curriculum ends and curriculum stance. The ends axis exhibits the tensions between vocationalism and liberalism whilst the tensions between reflection and action are exposed in the stance axis. Four key quadrants of curriculum space emerge and the characteristics of these quadrants are explored. A critique of curricula which are overly concentrated in the extremes of the framework is made which prepares the ground for the full articulation of the concept of the philosophic practitioner.

\section{THE PHILOSOPHIC PRACTITIONER: A CURRICULUM FOR TOURISM STEWARDSHIP}

\section{Methodology}

It initially needs to be asked what kind of research activity is underway in the development of a curriculum framework for higher education in tourism. This can be clarified by considering some instances of what is not being undertaken. The curriculum question is not, for example, one of cause and effect. We can therefore rule out experimental methods. The curriculum world is a different one to Popper's (1959, 1975) world of naturally occurring phenomena in the scientific world. Thus any solely scientific-empirical method is inappropriate. A model curriculum cannot be defined just by testing and measuring because it exists in the social rather than natural world. Curricula, as Young noted, "are no less social inventions than political parties or new towns." (1971:24). Ontologically speaking a curriculum is not a natural phenomenon which exists independently of human thought, just waiting to be discovered like a new planet or star. It is not therefore not just a matter of applying good observational skills or of devising the right instruments for its detection.

It is the aims and purposes of a tourism curriculum that are central to this article. Therefore the research methodology necessarily has a strong philosophical dimension. Indeed the method adopted consciously avoids the empirical on the grounds that the empirical may restrict our field of vision to what exists. Rather this article seeks to discover what might be. Lawton (1983, 1996), writing about curriculum design stressed the importance of an initial philosophical stage. This article follows Lawton's injunction that philosophical questions about the aims of education and the meaning of a worthwhile education must be raised and addressed. The curriculum aims set out here are those for achieving philosophic practitioners in tourism. Conceptual analysis is utilised to elucidate this term and the ideas underlying the concept - liberal tourism 
education, vocational tourism education, reflection and action in tourism - are analysed. Differentiation type analysis (Soltas 1968) is used to clarify these concepts.

\section{The curriculum concept of the philosophical practitioner}

The term curriculum has taken on a variety of meanings (Cooper et al. 1994; Graves 1983; Kerr 1968; Snyder 1971; Taylor and Richards 1985 and Young 1998). But for the purposes of this paper the curriculum is defined as a whole programme of educational experiences that is packaged as a degree programme. Its constituent parts are a number of modules or courses, which in turn may be specified as a series of syllabi or course contents.

The curriculum can be filled with different knowledge, skills and attitudes. Students embarking on tourism courses take different educational journeys according to the way in which their curriculum has been framed. Different framings mean that students will exit tourism courses with a variety of perspectives, attitudes and competences. The idea of framing (Bernstein 1971) is useful to understand that curriculum design involves choice where some components are included, and others excluded. Foucault (1971) also draws attention to fact that educational sites perform a role in selecting which discourses are to be disseminated. It is common for universities to frame their own tourism curricula, but surprisingly little discussion exists in the tourism literature about the aims and values that guide curriculum design.

The curriculum aims of the philosophic practitioner are to promote a balance between a tourism education that satisfies the demands of business and one that satisfies the demands of a more widely drawn tourism society and world. This curriculum uses knowledge from across the fields of tourism to encourage vocational competence balanced by ethical competence. Its underpinning values are that a vocational curriculum can provide improvement not only to the workings of business practices, but also to the wider tourism world which is related to and partially formed by business practices. This value may be described as tourism stewardship - a caring for the industry but also for the world which the industry makes and on which it depends.

There are two dimensions to the curriculum framework for philosophic practitioners. The first relates to that part of the world which is the focus of the curriculum. This is referred to as the ends of the curriculum. The second dimension relates to how the curriculum promotes engagement with these ends. This is referred to as the stance of the curriculum.

\section{Ends and stance}

Ends are represented by an axis which describes for what purposes the tourism curriculum is constructed and to what it is aimed. The ends of the tourism curriculum can comprise on the one hand vocational ends, focused on tourism employability and on the other hand liberal ends, focused on freedom of thought about tourism. These roughly coincide with ends which are closed and those which are open. The characteristics of knowledge and skills at the extremes of the ends axis are as follows. Where ends are vocational, the purposes of tourism education are extrinsic. These purposes are the pursuit of knowledge or performing actions for the external uses that these activities can be used for. There are special types of knowledge and actions that are valued here. A key influence on this part of curriculum space is performativity 
(Lyotard 1984). For example knowledge is selected for the curriculum here in response to particular questions:

"The question...is no longer 'Is it true?' but 'What use is it?' In the context of the mercantalization of knowledge, more often than not this question is equivalent to: 'Is it saleable?' And in the context of power-growth: 'Is it efficient?' " (Lyotard 1984:51)

This is knowledge that contributes to the efficiency of the business of tourism.

Where the ends of the curriculum are liberal they are unconstrained. Knowledge and actions are judged appropriate for different reasons. Here there is an intrinsic motivation and the pursuit of knowledge or actions themselves are their own ends. For example, knowledge is not chosen for performativity but rather because it satisfies some interests of the human mind. It may be knowledge which produces enjoyment, or which helps establish truths, or maybe knowledge which helps to progress an ethical argument of good or just tourism. The complete axis of ends therefore represents a continuum of possible aims and a source of potential tensions in the tourism curriculum.

Stance is the axis which describes different modes of study and expression which the tourism curriculum promotes towards its ends. The alternative stances that can be adopted in tourism education are those of reflection and action. Reflection is a mode of study that takes place in the mind. Here it is a question of gazing at the tourism world as lived, thinking about it and reviewing it. It is where:

"The good life for man is the life spent in seeking for the good life for man." (MacIntyre 1985:219)

It is a stance which emphasises critiques and scepticism about tourism and is characterised by the use of evaluative terms such as truthfulness, rightfulness, appropriateness and goodness. It is in this cognitive mode of study where theories about tourism may be constructed, understood, stated and mentally tested. One aspect of competence in the reflective mode therefore revolves around the ability to theorise about tourism. But reflection here implies more than just theory mastery. It implies establishing an intellectual position from which a range of competing theories and ideas about tourism can be surveyed and brought into play. Reflection enables a whole series of possible actions to be screened without having to practically test each. It also enables the basis for good tourism actions and interventions to be worked out.

Action is a mode of expression that takes place in the tourism world. It is getting on with things, involvement in aspects of tourism, doing, and engaging with the world as lived. The guiding principle of a curriculum for tourism action is effectiveness. Whereas reflection on tourism is relatively unbounded and can contemplate perfect situations (for example Plato's forms (Plato 1987) and tourism utopias), action is bounded by the pragmatism of what can be achieved given the constraints of the physical and the social environment. The complete axis of stance therefore represents a continuum of approaches to the tourism curriculum ranging from the practical to the theoretical. 
Having identified the dimensions of ends and stance underlying the curriculum concept of the philosophic practitioner, the mapping of the concept is completed when these axes are placed alongside one another to form a matrix. This is illustrated in figure 1.

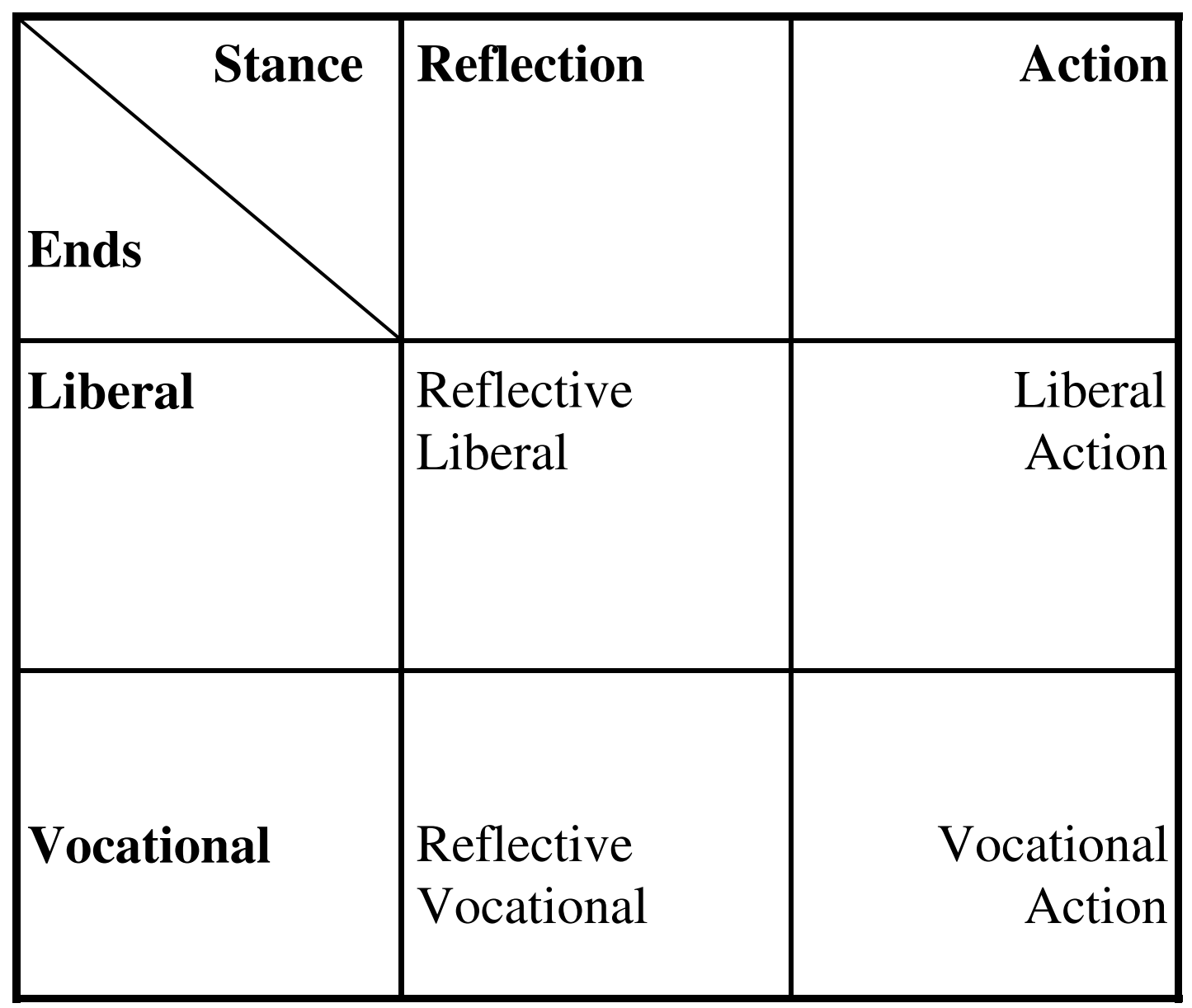

Figure 1. Ends and Stance

This matrix results in the identification of four key quadrants of the curriculum for philosophic practitioners. These are vocational action, liberal action, reflective vocational and reflective liberal. Each quadrant is now considered in turn with an emphasis on the unique features of each.

Vocational action and reflection in tourism

Pring explains that:

"vocational preparation signifies the acquisition of

skills, qualities, attitudes and knowledge that are judged

to be impotant for the world of work." (1993:60)

Just what this means for the tourism industry was identified by Haywood and Maki (1992) who found that the tourism industry valued practical and general transferable skills. Curriculum elements for vocational action that scored highly in Koh's (1995) study of tourism executives included communication skills, interpersonal skills, computer literacy, human resource management, managing service quality, marketing, managerial accounting, the travel industry and a practicum. 
By vocational action we are here referring to the actions of those employed in the tourism industry. So, for example, the marketing of a destination or an attraction, the management of a hotel or restaurant involve vocational actions. The aims and objectives of vocational action are simply defined as preparation for effectiveness at work. Its aim, to borrow Birch's (1988) terminology, is to enable students to become operational, and make a smooth transition into the world of work. Operational is used by Birch to signify an ability to perform in the commercial world and the types of knowledge and skills that underpin this kind of curriculum are mainly technical. In the domain of pure vocational action, the individual is limited to the role of potential manager and curriculum development involves the acquisition of specific vocational skills and knowledge and personal transferable skills for effectiveness at work. Effectiveness at work can include "flexibility" (Cooper and Shepherd 1997:42) and "the right attitude" (Cave 1997:7).

In the reflective vocational (Schön 1983) part of curriculum space there is an emphasis on reflection, evaluation and modification of tourism industry skills and knowledge. The development of individual or personal knowledge is encouraged. This is knowledge that is developed from experience and action in the world. Reflective vocationalism encourages the individual to personalise expertise and improve knowledge implicit in practices. The individual is encouraged to find his or her own voice for development and critique of vocational action. Reflective vocationalists are encouraged to stand back from their actions so that they may be subjected to critical review in the form of reflection-on-action. The point of this review is to evaluate action with a view to improvement and to evaluate differently constituted actions.

The territory of vocational reflection has been analysed in the work of Donald Schön. For Schön the importance of reflection-in-action was to provide a continual dialectic between the world as theorised about and the world as encountered. The art and artistry of the professional is thus built up from increased experience. A continual reflection on the world of theory and the encountered world enables the development of highly personalised and contextualised knowledge and skills. This is the development of an understanding which results in the interpretation and expression of theory and knowledge by the individual knower or practitioner. Vocational reflection contemplates on whether a presenting case fits an individual's current stock of theoretical knowledge. If not, he or she will consider how differences can be reconciled leading to a remodelling of personal knowledge.

In the tourism curriculum, there are several ways of promoting vocational reflection including the use of key or transferable skills, and work placements. For example Moscardo (1997) describes a concept of mindful managers for tourism which seems very close to vocational reflection. Key or transferable skills can also be important. The key skills of problem solving and flexible thinking are proposed by Moscardo as crucial components to mindfulness and the paper endorses the effectiveness of a series of exercises designed to create mindfulness. Work placement can contribute to vocational reflection particularly when there is an opportunity to debrief students on their experiences. Busby, Brunt and Baber (1997:106) include "the diagnosis and solutions of problems" as an important aim of placements for tourism students. 


\section{Liberal reflection and action in tourism}

The term reflective liberal is used to denote the quadrant where the reflective part of the stance axis meets the liberal part of the ends axis. Significantly, here reflection is not confined to vocational situations as it is with Schön. There are no limits restricting the ideas of liberal reflection whether they be set by the state, the education system, professional or business interests or indeed anyone. Creativity of thinking is allowed for. All is possible and so liberal reflection describes an infinite space of possible ideas. The three philosophical activities of attempting to uncover "the truth", a sustained scepticism about things and the search for "the good life" are central to most definitions of liberal education (Tribe 2000a) and these are all relevant to tourism.

The development of tourism knowledge and skills in this quadrant are assigned an open role. For example the Oxbridge tradition of liberal reflection promotes liberation from falsehood and therefore its curriculum requirement puts the pursuit of truth as a central requirement. Here the study of tourism is not a matter of improved business technique but of understanding aspects of the phenomenon. Typically, disciplinary or multidisciplinary modules are paramount here, for example geography of tourism, anthropology of tourism, sociology of tourism, economics of tourism and tourism social science. Such modules may also offer a sceptical view of tourism - but this may also be achieved by specific modules such as critical tourism studies, where critique, ideology, power and values are central. Here students are encouraged to find their own voices and develop critical agendas.

For Goodlad a curriculum which promotes "the good life" demands that "...some sort of facilitating activity is required ... offering students the opportunity ... to reflect on matters of ultimate concern." (1995:26). Goodlad is advocating that some part of the curriculum should develop the philosophical side of individuals, and encourage reflection on the meanings and purpose of life and in this case, the place of tourism in this bigger picture. Similarly the notion of becoming was developed by Freire (1972) as a process of transcending the moment and the present, and looking above, out and ahead to see what an individual or a society might or can become. Becoming therefore carries with it visions of the future and considerations of utopia. It is through modules such as philosophy of tourism, and tourism ethics (Hultsman 1995, Walle 1995) that "the good life" for tourism may be examined.

So the role of a reflective liberal curriculum is understanding and critical evaluation of tourism's society. Here is a conception of a curriculum which reflects upon tourism's world and the ethical issues associated with it. However, liberal action requires the extra step of translating better understanding and critiques of the wider world of tourism into action. Here ethical and just treatment of people (Apple 1990) and place affected by tourism are essential. This action may herald changes at the individual level, but may also be changes at a societal level in the form of collaborative action with others. The discourse of this quadrant of curriculum space therefore includes notions of world-making and liberation.

World-making assigns the curriculum a role in contributing to a changed tourism world. Action in the liberal, as opposed to the vocational sphere of the curriculum is given an open interpretation. There are no a priori limits on the world to be made 
therefore action in this sphere is unconstrained. So liberal action opens up the prospect of freedom of action. Where action is unconstrained this allows for a freedom of thought in liberal reflection. But liberal action implies more than just free thought. For this too can be limited to a case of creating a new world by reflection and keeping that new world in one's head. In this respect Krippendorf criticised...

"...the 'thinkers' who sit in their studies are political

lightweights. Their recommendations will remain

politically anaemic theories as long as there is no

pressure on the politicians..."(1987:107).

Liberal action requires that steps are taken literally to help create a new world, or as Freire explains:

"...creating and recreating...deciding and choosing and

ultimately participating in society's historical process."

(1972:30, my italics)

Liberal action represents transforming action. It represents a kind of action in the world which is distinct and different from Schön's (1983) reflective practice. Schön's reflective practice encourages reflection on action for improved action but is constrained by its vocational setting. Liberal action has no such constraints. It encourages reflection on all tourism practices in a wider world. Its object is improved tourism practices and not just improved tourism business practices. Practical steps to encourage the development of liberal action might include work placement with ethical tourism pressure groups (e.g. Tourism Concern), a module on the politics of tourism, a module on responsible tourism, and a philosophical practicum focused on the achievement of liberal action in tourism.

Finally liberation is a key aspect of liberal action. At a societal level, liberation has the meaning of movement from one form of organisation of society to another, where the move involves greater freedom for more people. This is an important consideration in balancing the interests of hosts and guests in tourism. In achieving the potential of the curriculum to fulfil its role as an agent for this kind of change Apple suggests the need for curriculum theorists to:

"affiliate with cultural, political and economic groups who are self-consciously working to alter the institutional arrangements that set limits on the lives and hopes of so many people in this society." (1990:166, italics in original)

So at its most radical, liberal action may some times challenge institutional arrangements of the business of tourism.

\section{Curriculum and ideology}

The articulation of four distinctive quadrants of curriculum space provides a framework to enable critical review of tourism curricula. Problems of partial framings can be seen in curricula that are over-concentrated in just one part of curriculum space. In some cases curricula may demonstrate such a narrow conception that the problem of ideology emerges. Indeed some key curriculum terms - operational, technical, vocational, liberal have been adapted to demonstrate the operation of an 
ideology. Hence we have the terms operationalist (Barnett 1994), technicist (Apple 1990), vocationalist (Tapper and Salter 1978), idealist and liberalist when we refer to a curriculum that is so narrowly driven by these aims that it admits no other purposes and the curriculum is insulated from other discourses. In these examples aims become strict regimes so that knowledge and skills that do not further such aims are not admitted into the curriculum. Regimes perform an act of closure on reflection and action.

Vocationalism and technicism

Consider a tourism curriculum with an exclusive emphasis on vocational action, for example the BA(Hons) Travel and Tourism Management at the University of Northumbria, UK. The aims of this degree are:

"to prepare [students] for a management career within the travel and tourism industry through a sound education in the principles and practices of management in the industry and to develop a set of personal skills and management competences appropriate for managerial careers in the travel and tourism industry." (University of Northumbria 1997:182)

The overriding aim is to deliver graduates to work in the tourism industry. Key attributes are those of utility and relevance. The course is governed by extrinsic goals, and technical efficiency. It appears to include a socialisation role in terms developing personal skills or what Dale (1985) referred to as "occupational adjustment".

A curriculum that is vocationalist legitimises a particular ideology characterised as one where "tourism is conceived of as a phenomenon which should be organised to bring profit to the organising enterprise and satisfaction to the paying tourist". Vocationalism limits those interests which enter the frame to those of employees in the tourism industry and tourists and it is therefore essentially a reproductive curriculum (Apple 1990) that supports, perpetuates and contributes to a narrow tourism society of consumers and producers. Under a vocationalist curriculum the existing world is taken as given and attention is applied to action in this given world. Means therefore take precedence over ends. Whilst means are honed, ends are taken for granted and alternative ends (and thus a whole series of moves in corresponding means) are lost from view. A concentration on means produces tourism graduates who devote their energies to the operationalizing of a blueprint which is given and the curriculum provides the technical expertise to fulfil the business aspects of tourism. This concentration on better technique (technicism) can mean that a view of the wider tourism world, embracing the critical and ethical, is lost.

Even where a curriculum for vocational ends is extended to include a reflective vocational element it does not necessarily escape criticisms of partiality and closure. For Schon's vocational reflection does not hold the whole tourism project up for critical scrutiny. Vocational reflection does not escape world-taking. In the reflective domain of the vocational tourism curriculum, reflection is limited to the area of business actions. Reflective practice may encourage critique of these practices, but even the modified actions resulting from reflective practice will still be directed towards business ends. Reflection is not permitted to generate a line of thinking that takes it beyond the closed world of business actions. It is therefore not open reflection 
but operates under constraints. Reflective practitioners do not make the major move from the reflective to the philosophical. They do not engage in philosophical reflection about the ends of their vocational actions. They reflect largely within the constraints of what is, and only consider the what might be from a technical perspective.

\section{Liberalism and academicism}

Just as vocationalism implies closure so does liberalism. A tourism curriculum framed solely for liberal ends may be criticised as one which has turned its back to the world of work. The M.A. in the Sociology and Anthropology of Travel and Tourism at the University of Surrey, Roehampton, UK, illustrates such a course.

"The key areas of study in this course are Introduction to the Sociology and Anthropology of Travel and Tourism; Tourism and the Global Culture; Thesis Writing; Tourism, Heritage \& Environment; Space, Place and Society; Tourism, Myth and Pilgrimage; Travel Writing and Media Representations; Dissertation." (University of Surrey Roehampton 2000:63)

Here, liberal reflection as an exclusive focus for a curriculum can lead to different problems of partiality coming close to what Goodlad has termed "academicism". Goodlad explains its shortcomings as follows:

"...it indicates a detachment of the individual (academic or student) from any realistic perception of what is either socially desirable or practically meaningful." (1995:28)

In fact The University of Surrey, Roehampton's largely reflective liberal curriculum does clearly consider social desirability with its emphasis on disciplinary insights from sociology and anthropology. But there appears to be little emphasis on knowledge or skills that have practical application and little preparation for courserelated employment. Indeed there is the temptation in pure reflective liberalism to loose sight of the realities of having to make a living in the world. Truth seeking may become debilitating and students may seek refuge from the difficult realities of the tourism world in an arcane world of philosophising.

There are further criticisms of any curriculum that is located entirely in reflective liberalism. They are criticised by Birch for leading to closed-system tendencies which are explained as:

"...the propensities to operate largely from internally generated stimuli and to validate the responses within the relatively closed circle of international scholarship." (1988:4)

Birch is referring here to the existence of academic enclaves and ivory towers which operate in a parallel sphere insulated from, and unconnected to, the world of business. Here it is possible for the tourism world to be inspected at arms length, and for prognostications about that world to be made without regard to the practical realities of competitive business conditions. Theorising here is made easier because there is no 
intention to make a move from the world of thought to the world of vocational actions. To counteract the influences of liberalism and academicism Birch urged that higher education:

"must address itself to the extrinsic needs of society as well as the intrinsic needs of scholarship...[and develop] the operational notion that knowledge should be put to work." (1988:64)

\section{The Philosophic Practitioner}

Recent research points to the existence of partial and incomplete framings of tourism curricula. For example Airey points out that

"Tourism education has come in for criticism in the past because of the extent to which courses have been dominated by thinking that is rooted in economics and business studies." (Airey 1997:10).

Additionally, a study of tourism degree courses in the UK concludes that "...course aims and objectives reveal that most of the courses on offer are vocational in orientation and within this business issues are normally well developed." (Airey and Johnson 1999:234)

It is as a response to issues of partial framings that the concept of the philosophic practitioner is developed, mapping a tourism education which is conscious of, and responds to, wide aims for the tourism world. Vocational action is extended to include vocational reflection and liberal reflection is extended to encompass liberal actions. Now the philosophic practitioner clearly has stirrings of Schön's Reflective Practitioner $(1983,1987)$ in its title. It certainly builds upon Schön's model that invites the curriculum to develop competent, but reflective practitioners. After all as tourists, we all want tourism services that are efficient, effective, innovative and economical. But this new model deploys additional concepts which locate its tourism graduates on a more philosophical plane than Schön, whilst at the same time requiring active engagement with the world of tourism.

The elements of the philosophical practitioner curriculum can be found in figure 2 where the matrix that divides up curriculum space is revisited. Notice that a philosophic practitioner would graduate from a curriculum that develops knowledge and skills in all four domains. Although the domains remain separated out for the sake of conceptual clarity, integration is to be aimed for in this curriculum model. 


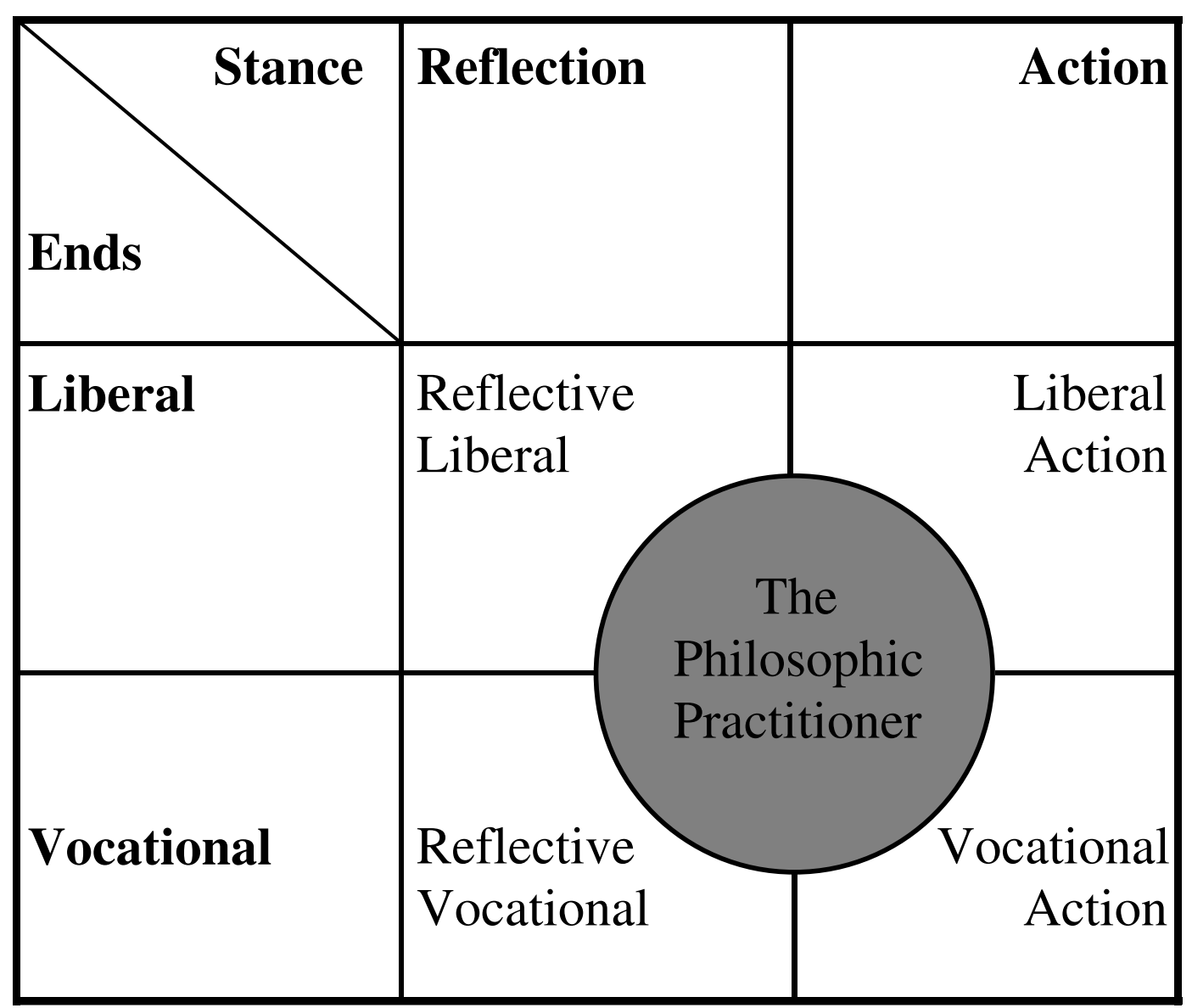

Figure 2. The Philosophic Practitioner

A philosophic practitioner must have the potential to practise in the tourism industry. It is the curriculum for vocational action that underpins the vocational, extrinsic aim of a tourism higher education and prepares the philosophic practitioner to operate effectively in an occupational role. So one element of philosophic practice entails the ability to engage in high quality and competent actions in tourism operations.

The reflective part of the vocational axis is the initial point of departure from narrow vocational action towards philosophic practice. Here, a limited type of philosophising emerges that is reflection on vocational action. We may conceive of the reflective practitioner in the sense elaborated by Schön who alerted us to the gap between knowledge gained in an academic setting and the use of that knowledge in a practical setting and the importance of reflection-in-action and the development of "professional artistry". Next, the term philosophic practitioner gains an important aspect from liberal reflection and it is here that the philosophical part of the term comes into fuller play. In this domain, philosophic practitioners need to develop knowledge and skills that will enable them to operate in a philosophical mode and recognise the partiality of the world of operations and technical problem solving. Their philosophical development would enable them to transcend this partial world and tune into the bigger picture with its complex world of tourism - both the business and non business domains of the phenomenon of tourism - by utilising a broader range of tourism knowledge. The formulation of critiques of this bigger world of tourism tourism's society - becomes a major task for the reflective liberal. 
So the philosophic practitioner in liberal reflection may view tourism from the perspective of different disciplines, to extend the view from a mainly business position and to adopt an anthropological view, a philosophical view, a sociological view or an environmental view. The reflective liberal will venture far beyond Schön and engage in discourses that scrutinise the "what is" and compare it to the "what might be". These are not just discourses concerned with profitability (though these may certainly be important), and not just those related to the improvement of a product or service. Rather, any discourses that concern the whole world of tourism, without presupposition, may be engaged in.

Whilst sustained critical thinking is central to liberal education, it is a fourth domain containing the concept of liberal action which completes the curriculum framework for the philosophic practitioner. Liberal action refers to the sense in which the philosopher can do more than philosophise. Thus the term implies not just the practising of philosophy, but also the putting into action of the fruits of such philosophising. This means not just stopping at the point where the world is seen in a different way. It implies getting out of the philosopher's armchair and engaging in action. The philosopher (operating just out of a liberal reflective curriculum) might, having constructed a mental conceptual and analytical map of a particular problem, see that problem in a new light. But the litmus test of liberal action is action and achievement of change. Liberal action might include lobbying for a particular cause, pressure group or other political activity. But liberal actions are not confined to situations external to occupations. Liberal activists can be the conscience and instigators of ethical action within the workplace. The hallmarks of liberal activism are knowing-in-action and practical wisdom. This is promoted by the cultivation of judgement and good action for the community. Barnett notes that:

"Institutions of higher education can become a microcosm of the rational society, a reminder to society of what society itself might be." (1990:121)

And this demonstrates clearly the difference between reflective and active liberalism. For liberal action does not just remind society how tourism might develop for the better, but seeks to participate in the process of achieving betterment.

At first glance there seems perhaps little that is novel in the proposal for the philosophic practitioner. Specifically in tourism education there already exist modules on responsible tourism and environmental tourism for example. More generally in higher education, curriculum theorists have long argued that vocational elements need to be balanced with liberal elements. Indeed writers such as Silver and Brennan (1988) have suggested that many degree courses do in fact achieve this aim and deliver a liberal vocationalism. Additionally, as Barnett notes, higher education as a whole does provide coverage across curriculum space so that it:

"produces technicist, managerial and economic ideologies for society; and it produces critical ideologies

- e.g. ecological, feminist, deconstructionalist and humanistic ideologies - consciously counterpoised against the former set." (1990:71) 
Barnett's observation captures a key challenge for the philosophic practitioner. This is related to the idea of partiality of the curriculum and the problem of academic division of labour. This division of labour, alluded to by Newman (1853), has resulted in a specialisation where the higher education system can produce managers, and accountants separately from sociologists and philosophers. There are technicist curricula that aim to deliver means to achieve given ends and critical curricula that hold ends up for critical scrutiny. What is missing is a synthesis of critical thinking into vocational courses as an antidote to technicism. Equally a synthesis of vocational realism into purer critical thinking courses is missing allowing critical thinking to ignore its relationship to the working world.

Now this synthesis may be difficult to achieve and several writers have rehearsed the barriers to this kind of integration. For example, Cotgrove (1983) has described how these different camps represent different paradigms. Following Kuhn's (1970) notion of paradigms we may conclude that different paradigms have their own internal logic and procedures, each of which is alien to the other. Becher's (1989) concept of Academic Tribes adds weight to this idea of division in its description of academic communities that form tight groups with agreed rules. Additionally the condition termed by Lyotard (1988) as a differend has relevance here. The case of a differend arises when there is no discourse or tradition common between two parties and a lack of agreed rules therefore prevents each party from engaging with the other.

The principles underpinning the development of a curriculum for philosophic practitioners are summarised in table 1 . The concept offers a way of unifying these discrete traditions and engaging with the problem of the differend. The aim of this curriculum will be to develop a common agenda and a shared language so that a number of dualisms are bridged. This would encourage communications first between those operating in the business world of tourism and those in its non-business world, and second, between those in the lived world of tourism (tourism actions) and those in the thought about world of tourism (tourism reflections). An associated effort is also necessary to tackle the dualism where fact and values are separated so that both facts and values are given space in the curriculum.

\section{Aims and roles}

Philosophic practitioners will be firmly rooted in the world of day-to-day vocational actions, aiming to be competent and efficient, but also able to operate beyond this narrow world of practice. The twin aims of philosophic practitioners are therefore to deliver better tourism services and to contribute to the construction of a better tourism world and therefore to learn how to work in tourism and for tourism. MacIntyre's (1985) observation that modernism has led to the partitioning of human roles points up the challenge for philosophical practice. This is to develop and seek to reconnect two key roles that have become separated. These are the roles of the occupational person in tourism and the responsible person overseeing and participating in tourism development. 
Table 1. The philosophical practitioner

\begin{tabular}{ll}
\hline Aims & better tourism service \\
Roles & better tourism world \\
& occupational competence \\
& stewardship for tourism \\
Ends & vocational: consumers and producers \\
& liberal: stakeholders and places \\
Stance & reflection \\
& action \\
Epistemology & business interdisciplinarity \\
& extradisciplinarity \\
& multidisciplinarity \\
& general interdisciplinarity \\
& knowing in vocational action \\
practical wisdom & technical \\
communicative \\
to be exposed (e.g. vocationalism, academicism) \\
an unbounded view of tourism's world, including tourism \\
Ideology & satisfaction, efficiency, profit, effectiveness, productivity, \\
Issues and values & environment, justice, equality, aesthetics, ethics, culture and \\
history & tourism's society: tourists, business and non-business interests \\
\hline
\end{tabular}

It is complementary role development for occupational competence and responsibility that provides for this. Stewardship is a potent idea where philosophic practitioners assume the responsibility for promoting the well being of tourism's society and world and not just the profitability of individual firms. Stewardship is a term borrowed from environmentalism. It implies the long term care of tourism, making sure that it is not damaged or mis-used. Management of externalities is central to stewardship. This implies watchfulness of the use or development of tourism with regard to the consequences of its exploitation to a range of stakeholders. These stakeholders include direct users, indirect users, and future generations. Stewardship implies an active and not just a passive stance to developments so it is a key component of liberal action. Of course stewardship needs to incorporate occupational role development in tourism, so that the hard realities of earning a living are not overlooked.

\section{Ends and stance}

The idea of ends and the importance of visioning alternative ends is central to the idea of the philosophic practitioner. Here the business ends implicit in vocationalism and the free ends contemplated in liberalism are each given due weight. Additionally, the notions of tourism's society and the tourism world signal the elevation of the status of people and place to be included as significant ends of the tourism project. This is a crucial difference in emphasis first from vocationalism where people and place are the means to achieving the ends of business profitability and consumer satisfaction and second from liberalism where ends may be constructed without consideration of pragmatic means.

Regarding stance, Arendt (1958) noted that those involved in thought and those involved in action had taken different paths, and it is this separation of reflection and action that presents a further challenge to philosophic practice. The term itself clearly carries a commitment to avoid either action which is not subject to reflection or reflection which does not have some recourse to action. It is the development in 
students of an awareness of knowing in action, and reflection before, in and after action both for vocational and liberal ends that is important to achieve the full potential of philosophical practice.

This linking of reflection and action enables the nuances of action specific to philosophic practitioners to emerge. A curriculum for philosophic practitioners promotes two meanings of action. Arendt (1958) described a change in the meaning of actions from the Aristotelian notion of actions which have goods internal to themselves, to the modern usage of action as making things or fabrication. Furthermore, MacIntyre (1985) suggested that good practices in the Aristotelian sense have been marginalised. A vocationalist curriculum is one which promotes actions as fabrication. A curriculum for philosophical practitioners embraces this usage of the term but extends usage to the Aristotelian sense. It promotes a background dialectic between the good action as an efficient and effective vocational action and the good action as one which measure up to some ethical standards of goodness for the tourism community. So reflection here provides an ethical check on actions.

\section{Epistemology and rationality}

The epistemological key to the curriculum for philosophic practitioners is that knowledge is used from the whole field of tourism studies (Tribe 1997). The importance of this, is that business interdisciplinary knowledge and extra-disciplinary knowledge exert a dominance over vocationalist tourism studies. This kind of knowledge creation is motivated by the profit motive and what Lyotard (1984) described as performativity. To use the geneticists' metaphor, business interdisciplinarity represents a dominant gene - it is the grey squirrel of tourism studies. A curriculum for philosophic practitioners balances this knowledge with multidisciplinary and general interdisciplinary knowledge. It is this crucial balance that equips students with the knowledge breadth that enables a free analysis of the tourism phenomenon to take place. The student is freed from the kind of partial knowledge perspective that limits and constricts understanding of the tourism phenomenon.

Communicative reason (Habermas 1989, 1991) represents an important contribution to decision making in addition to technical rationality for philosophic practitioners. There is a tendency to favour technical rationality in vocational tourism using quantitative tools. Market prices are used where they exist and for those tourism aspects which are unpriced - for example the preservation of a building, the use of a forest for recreational purposes, or the preservation of a view - shadow prices are allocated. This move enables quantitative decision-making equations to be made based on a comparison of numerical values (normally the costs and benefits of a scheme based on monetary values). The attractiveness of these schemes is that they dispense with arguments based on language which are difficult to weigh up and compare and replace them with a series of equations. Decisions are then made based on the ordering of options according to their numerical result. Of course the very simplicity of this approach belies many of the assumptions that have to be made to allow for that simplicity. Against this tradition, philosophical practitioners would promote communicative rationality for decision making where the situation demands it. The richness and complexity of decision making is allowed and aesthetic and ethical factors are not translated crudely into numeric equations but given their full voice through the language system despite the difficulties of comparing arguments. 


\section{Ideology, issues and interests}

Just as Habermas (1978) noted the relationship between knowledge and human interests, curricula can serve different interests too. The important issue for the curriculum for philosophical practitioners is to avoid domination by any particular interest. Philosophic practice is an antidote to vocationalism where business and consumer interests can be so exclusive as to amount to an ideology which controls the tourism project. Equally the philosophic practitioner curriculum allows no retreat into other ideologies such as liberalism, or Marxism. No partial curriculum is admissible so that no act of closure can be imposed by the curriculum. It is the conscious competition encouraged in this framework between the major interests of tourists, tourist business, other stakeholders and the physical environment that guards against ideology. Interests and values are not just profit (vocationalism) or tourism satisfaction (hedonism) or ecology (environmentalism) or equality (socialism) but pluralistic. This offers the prospect for the business of tourism to develop within a wider ethical framework where a range of values is given due weight. Multiple values challenge the situation where "managers...conceive of themselves as morally neutral characters whose skills enable them to devise the most efficient means of achieving whatever end is proposed". (MacIntyre 1985:74).

A final question: How will a philosophical practitioner negotiate the world as lived? Having been educated under such a framework it might be that a graduate finds work as a marketing manager for a major airline. The philosophic practitioner will engage in vocational action to establish a marketing position, for example, that will beat the competition and gain more custom. Vocational reflection would be deployed which might lead to a constant dialogue with colleagues to review and improve this strategy. It would promote an interplay between conceptual schemes and practical experience that result in continual, adaptive learning. However, at the same time, liberal reflection might lead to a recognition that the environmental effects of increased air traffic are becoming more and more serious.

So the philosophic practitioner may then seek to operationalise a solution to such discovery, perhaps by joining a pressure group, perhaps by lobbying against the construction of a runway in an environmentally sensitive area or by offering alternative strategies to related problems arising at work. A philosophic practitioner may work within a given value system whilst at the same time perhaps working to try to change some of the values of that system. What is sought is the development of practical wisdom and action in the wider tourism world at the same time as earning a living in, and contributing to the economic development of a specific business domain of tourism. This is working in tourism whilst taking responsibility for stewardship of the developing world of tourism.

\section{CONCLUSION}

A key task of this paper has been to locate tourism actions in two contexts. These are vocational tourism, with an emphasis on instrumental action governed by values of production, and that of liberal tourism where values and ends are more open. Combining these two contexts has delivered the full complexity of the tourism world upon which action can be taken. The other key task has been to promote the notion of reflection. Here, the juxtapositioning of reflection and action for vocational and non- 
vocational ends enables Schön's narrow conception of reflective practice to be extended so that the concept which is the title of this paper - the philosophic practitioner - emerges fully.

In conclusion, philosophic practitioners in tourism will be able to sell themselves in the market place as productive employees. Society expects its workforce to be well trained, and expects to recoup its investment in higher education in terms of enhanced economic performance. But any deep consideration of the term society surely moves beyond society-as-consumers-and-producers, and generates questions about what kind of tourism society we want to develop. The philosophic practitioner curriculum is designed to satisfy the labour market, to satisfy consumer wants, and to promote economic welfare. It is also designed to create a reflective workforce to further the debate about the destiny of the tourism world and an active workforce to create a tourism society that has been thought deeply about. It will intervene in the simple, yet potentially dangerous cycle of reproduction of the world "as is" where students learn passive adaptation to the tourism world that exists (Minogue 1973). It will contribute to the task of tourism world-making. The philosophic practitioner offers a curriculum which plays up students' future role in stewardship as well as employment. The result is that people in tourism's society and place in the tourism world become ends as well as means in the project of tourism and the vocational world of tourism is situated in, and coupled to, the wider tourism life-world. Philosophic practitioners would think and act for tourism world-making.

Acknowledgement - The author would like to thank Ronald Barnett, Dean of Professional Development, Institute of Education, University of London, for comments on this paper.

\section{References}

Airey, D.

1997 After 25 Years of Development: A View of the State of Tourism Education in the UK. In The ATTT Tourism Education Handbook, E. Laws, ed., pp. 9-12. London: Tourism Society.

Airey, D., and S. Johnson

1999 The Content of Tourism Degree Courses in the UK. Tourism Management 20:229-235.

Apple, M.

1990 Ideology and the Curriculum. London: Routledge and Kegan Paul.

Arendt, $\mathrm{H}$.

1958 The Human Condition. Chicago: University of Chicago Press.

Barnett, R.

1990 The Idea of Higher Education. Buckingham: Open University Press.

Barnett, R.

1994 The Limits of Competence. Buckingham: Open University Press.

Becher, T.

1989 Academic Tribes and Territories. Buckingham: Open University Press.

Bernstein, B.

1971 Classification and Framing. In Knowledge and Control, M. Young, ed., pp. 47-69. London: Collier Macmillan. 
Birch, W.

1988 The Challenge to Higher Education. Buckingham: Open University Press.

Busby, G., Brunt, P., and S. Baber

1997 Tourism sandwich placements: an appraisal. Tourism Management 18(2):105-110.

Cave, $\mathrm{P}$.

1997 Placements in Industry - Experience in the Lancashire Business School. London: National Liaison Group for Higher Education in Tourism.

Cooper, C., and R. Shepherd

1997 The Relationship Between Tourism Education and the Tourism Industry: Implications for Tourism Education. Tourism Recreation Research 22(1):34-47.

Cooper, C. Shepherd, R., and J. Westlake

1994 Tourism and Hospitality Education. Guildford: University of Surrey.

Cotgrove, $\mathrm{S}$.

1983 Risk, Value Conflict and Political Legitimacy. In The Hidden Curriculum in Business Studies, D. Graves, ed., pp. 47-54. Chichester: Higher Education Foundation.

Dale, R.

1985 Education, Training and Employment. Oxford: Pergaman Press.

Foucault, M.

1971 L'ordre du Discours. Paris: Gallimard.

Freire, P.

1972 Pedagogy of the Oppressed. Harmondsworth: Penguin.

Goodlad, S.

1995 The Quest for Quality. Buckingham: Open University Press.

Graves, D., ed.

1983 The Hidden Curriculum in Business Studies. Chichester: Higher Education Foundation.

Habermas, J.

1978 Knowledge and Human Interests. London: Heinemann.

Habermas, J.

1989 The Theory of Communicative Action (Vol. 2). Cambridge: Polity Press.

Habermas, J.

1991 The Theory of Communicative Action (Vol. 1). Cambridge: Polity Press.

Haywood, K., and M. Maki

1992 A Conceptual Model of the Education / Employment Interface for the Tourism Industry. In World Travel and Tourism Review, J.R.B. Brent Ritchie and D. Hawkins, eds., pp. 237-248. Oxford: CAB International.

Holloway, C.

1995 Towards a Core Curriculum for Tourism: A Discussion Paper. London: The National Liaison Group for Higher Education in Tourism.

Hultsman, J., 1995, Just tourism. An ethical framework, Annals of Tourism Research 22(3): 553-567.

Kerr, L., ed.

1968 Changing the Curriculum. London: University of London Press.

Koh, K.

1995 Designing the Four-year Tourism Management Curriculum: A Marketing Approach. Journal of Travel Research 33:68 -72.

Krippendorf, J. 
1987 The Holiday Makers. Oxford: Butterworth Heinemann.

Kuhn, T. S.

1970 The Structure of Scientific Revolutions. Chicago: University of Chicago Press.

Lawton, D.

1983 Curriculum Studies and Educational Planning. London: Hodder and Stoughton.

Lawton, D.

1996 Beyond the National Curriculum. London: Hodder and Stoughton.

Lyotard, J.

1984 The Postmodern Condition: A Report on Knowledge (Trans. G. Bennington and B. Massumi). Manchester: Manchester University Press.

Lyotard, J.

1988 The Differend: Phases in Dispute (trans. G. Van den Abbeele). Minneapolis: University of Minneapolis Press.

MacIntyre, A.

1985 After Virtue. London: Duckworth.

Minogue, K. R.

1973 The Concept of a University. London: Weidenfeld.

Moscardo, G.

1997 Making mindful managers. The Journal of Tourism Studies 8(1):16-24.

Newman, J.

1976 (orig. 1853) The Idea of a University. Oxford: Oxford University Press. Plato

1987 (orig. 375 BC) The Republic (trans. D. Lee). Harmondsworth: Penguin Books.

Popper, K.

1959 The Logic of Scientific Discovery. London: Hutchinson.

Popper, K.

1975 Objective Knowledge: An Evolutionary Approach. Milton Keynes: Open University Press.

Pring, R.

1993 Liberal Education and Vocational Preparation. In Beyond Liberal Education, R. Barrow and P. White, eds., pp. 41-75. London: Routledge.

QAA (Quality Assurance Agency for Higher Education)

2000 Subject Benchmark Statement for Hospitality, Leisure, Tourism and Sport. Gloucester: QAA.

Schön, D. A.

1983 The Reflective Practitioner. London: Maurice Temple Smith.

Schön, D. A.

1987 Educating the Reflective Practitioner. London: Jossey-Bass.

Soltas, J. F.

1968 An Introduction to the Analysis of Educational Concepts. Reading: Addison Wesley.

Shepherd, R.

1997 The Graduate Tourism Aptitude Test (GTAT). In The ATTT Tourism Education Handbook, E. Laws, ed., pp. 70 - 76. London: The Tourism Society.

Silver, H., and L. Brennan

1988 A Liberal Vocationalism. London: Hodder and Stoughton. 
Snyder, B.

1971 The Hidden Curriculum. Cambridge Mass. and London: MIT Press.

Tapper, T., and B. Salter

1978 Education and the Political Order. London: Macmillan Education.

Taylor, P., and C. Richards

1985 An Introduction to Curriculum Studies. Windsor: NFER-Nelson.

Tribe, J.

1997 The Indiscipline of Tourism. Annals of Tourism Research 24:638-657.

Tribe, J.

1999 The Concept of Tourism: Framing a wide tourism world and broad tourism society. Tourism Recreation Research 22:75-81.

Tribe, J.

2000 a Balancing the Vocational: The theory and practice of liberal education in tourism. Tourism and Hospitality Research 2:9-26

Tribe, J.

$2000 \mathrm{~b}$ The National Curriculum for Tourism Higher Education. In Guideline 9: Benchmarking and the Higher Education Curriculum, D. Botterill and J.Tribe, pp. 2-12. London: National Liaison Group for Higher Education in Tourism.

University of Northumbria

1997 Undergraduate Prospectus, 1998 entry. Northumbria: University of Northumbria.

University of Surrey, Roehampton

2000 Graduate Prospectus. London: University of Surrey, Roehampton.

Walle, A. H.

1995 Business ethics and tourism: from micro to macro perspectives. Tourism Management 16(4): 263-268.

Young, M., ed.

1971 Knowledge and Control. London: Collier Macmillan.

Young, $\mathrm{M}$.

1998 The Curriculum of the Future. London: Falmer Press. 